\title{
The Ideology of the New Right and Religious Conservativism. Towards an Ethical Critique of the New Politics of Authoritarianism ${ }^{1}$
}

\author{
Hans Schelkshorn
}

This article analyses the ideological matrix of the so-called right-wing populist movements, which was developed by Alain de Benoist, the founder of the Nouvelle Droite in France. The ideology of the New Right breaks with two dogmas of the old fascism: racism and the abolition of democracy. De Benoist replaces racism with ethnopluralism and aims at a radical reform of democracy. Inspired by the model of Athenian polis, de Benoist propagates the concept of an "organic democracy" based on ethnic homogeneity. Thus, the idea of pre-state human rights is criticized as ideological product of Christianity and the Enlightenment. For that reason, the ideology of the New Right has not only an illiberal but also a neo-pagan agenda. For that reason Christian alliances with new-rightist movements involve themselves in ideological contradictions. The perversions of Christian ethics through an ethnic concept of democracy can be illustrated by Victor Orbán's foundation of an "illiberal state" in Hungary. Thus, this ideology aims to erode both the democratic constitutional state and the universalistic dimension of Christian ethics.

Theories of Democracy; Populism; Human Rights; Christian Ethics

Hans Schelkshorn is head of the department for Christian Philosophy at the University of Vienna. He studied philosophy, Catholic theology and classical philology in Vienna and Tübingen (Germany). He completed his habilitation at the department of philosophy at the University of Vienna in 2007. His main research fields are ethics, philosophy of religion, political philosophy, intercultural philosophy with a focus on Latin American philosophy, and theories of modernity. He is member of the research-center "Religion and Transformation in contemporary society" (RaT), co-editor of the journal "PolylogZeitschrift für interkulturelles Philosophieren" (www.polylog.net) and president of the Viennese Society of Intercultural Philosophy (WIGIP).

\section{Introduction}

After the fall of the Berlin Wall, Francis Fukuyama celebrated liberal democracy as the endpoint of the ideological evolution of mankind (Fukuyama 1989). A few decades later, liberal democracy is challenged not only in some peripheries but

1 The present article is a revised and extended version of Schelkshorn 2017. 
even in the core states of the so-called Western world. Since the victory of Donald Trump, even the democratic order of the United States has been shattered.

The Mexican philosopher Leopoldo Zea, however, already criticized Fukuyama's euphoria on liberal democracy in the early 1990s. According to Leopoldo Zea, Fukuyama ignored the most important historical lesson of the $20^{\text {th }}$ century, namely that the liberal world-order provoked the emergence of fascism that threw the whole of mankind into a humanitarian catastrophe. In the light of Fukuyama's uncritical over-emphasis of liberal democracy, the $20^{\text {th }}$ century appears only as a lost century (una centuría perdida) (Zea 1996, pp. 13-22). In fact, at the beginning of the $21^{\text {th }}$ century neo-liberal globalization and intensified migration flows have led to the emergence of new rightwing parties in almost all western countries, including Latin America (Heinisch / Holtz-Bacha / Mazzoleni 2017) The rise of the New Right, however, is not a completely new event in recent history. The Front National, the first important New Right party in Europe, was founded in 1972. In the mid-1980s, Jörg Haider, the head of the Austrian Freedom Party (FPÖ), became a second leading figure of the New Right in Europe. Meanwhile, the spirit of the New Right has crossed the limits of right-wing populist parties, spreading its ideological topics into the middle-classes and civil society including Christian milieus. In present times, Viktor Orbán, a Christian Democratic politician and member of the Reformed Church, is generally acknowledged as the new political leader of the New Right in Europe.

Christians aren't only uninvolved spectators or blind followers of the New Right. Jörg Haider was already supported by ultra-conservative bishops. Nowadays conservative Catholics as well as evangelical Protestants are engaged in the Alternative for Germany (AfD). Viktor Orbán holds a strong alliance not only with the Reformed Church, but with the Catholic episcopate, too. Jaroszlaw Kaczýnski, the Leader of "Law and Justice" (PiS), expressed his gratefulness to Radio Maryja movement without whose support the election victory in 2015 would not have been possible. ${ }^{2}$

In public media as well as in social sciences extreme rightwing parties are usually analyzed as "populism", referring mainly to certain strategies, for instance friend-enemy scheme, separation of society into the "true people" and the "corrupt elite", simplification of complex facts, the mobilization of resentments, etc. (Canovan 1981; Mudde 2007; Müller 2016, pp. $11 \mathrm{f}$.). In this view populist parties are considered as political movements without a thick ideological orientation, adapting political issues mainly to the fluctuating moods of the "people" (Taggart 2000; Priester 2012). The rise of populisms seems to react only to a crisis of representation within the hegemonic liberal political culture, a crisis which is hidden by the so-called mainstream media.

2 For detailed analyzes of the relationships between Christian groups and new rightest movements in Europe and the USA see Marzouki / McDonell / Roy 2016. 
The public image of populism as an almost unideological political movement, however, underestimates the political agenda of the New Right, which aims at an erosion and ultimately authoritarian transformation of liberal democracy. Thus, Victor Orbán's well-known proclamation of an "illiberal state" clearly expresses the ideological focus of the new rightest movements despite their political differences.

The question of the relation between populist parties and a crisis of representation presupposes an accurate analysis of their ideological orientations. Thus, in the following sketches I would mainly analyze the ideological matrix of the New Right referring to Alain de Benoist, the founder of the Nouvelle Droite in France (chapter 1). In a second step, I will examine the ideological orientation of Fidesz as the most important example of a Christian New Right politics today and its contradictions with Christian ethics (chapter 2). In a final remark I will indicate deficits in contemporary political philosophies which undermine a strong secular criticism of the New Right.

\section{The Ideological Matrix of the New Right: Alain de Benoist}

As political analysts often emphasize, populist parties pursue quite different social and political objectives due to the history and heterogeneous members of these parties. For instance, the FN and the FPÖ were originally succesor parties of former fascist groups. Having evolved to the largest worker's parties in their countries, FN and FPÖ adopted some socialist themes in their programs. By contrast, the German AfD originally founded by conservative liberals promotes primarily neoliberal economic views criticizing the socialist agenda of the FN. Populist parties differ also in the foreign-policy interests. Since Victor Orbán intensified the relationships to Putin, the Polish government still maintained a distant attitude towards Russia.

Despite all the different political issues, the so-called right-wing populist parties share a common ideological matrix which modifies their conservative, liberal or socialist orientations in a certain way. The main ideological elements of the broad spectrum of new rightest movements can be found in the philosophy of Alain de Benoist, the master mind of the Nouvelle Droite in France. Inspired by Antonio Gramsci, de Benoist aimed to break the cultural hegemony of left and liberal thinking in the Western World. Therefore de Benoist didn't found a new party but a forum for right-wing intellectuals, the "Groupement de recherche et d'etudes pour la civilisation européenne" (GRECE) in 1968. As de Benoist declares in his "Manifeste pour une renaissance européenne (1999)" the Nouvelle Droite "is not a political movement, but a think-tank and school of thought" (de Benoist / Champetier2012, p.11).

According to de Benoist, the New Right must dissolve itself from two dogmas of fascism, concretely the biological racism and the option for a violent destruc- 
tion of democracy. Thus, the New Right replaces racism with ethnopluralism and aims at a radical reform of democracy.

In the early 1960's, Alain de Benoist himself publicly justified racism and the superiority of the white race in his early neo-fascist period (Taguieff 1994, pp. 111122-135; Böhm 2008, pp. 160-172). The emphatic claim to abandon the racist dogma of "old" fascism marks a certain break within his intellectual biography. Indeed, de Benoist distanced himself from all the three elements of racism: the postulate "of qualitative inequalities between races, such that, on the whole, one can distinguish races as either 'superior' or 'inferior'; that an individual's value is deduced entirely from the race to which he belongs; and that race constitutes the central determining factor in human history. These three postulates may be held together or separately. All three are false." (de Benoist/ Champetier2012, p. 33; cf. de Benoist 1974-75). At the same time de Benoist refuses the cosmopolitanism of the enlightenment, because its abstract universalism ignores the integrity of other cultures. In addition, modern cosmopolitanism served as ideological justification for imperial expansion and "its subsequent attempt of convert the rest of the world: in the past, to its religion (the Crusades); yesterday, to its political principles (colonialism), and today, to its social model (development) or its moral principles (human rights)" (de Benoist / Champetier2012, p. 28). Thus, criticism of imperialism and globalization are no longer a monopoly of left wing intellectuals, but a core feature of representatives of the New Right, too.

Beyond racism and abstract antiracism the New Right defends a "differentialist anti-racisms" acknowledging the irreducible plurality and Otherness of cultures (de Benoist / Champetier2012, p. 34). De Benoist views modern world as a "pluriversum, a multipolar order in which great cultural groups find themselves confronting one another in a shared global temporality"3. "Rather, the struggle against racism is waged by the refusal of both exclusion and assimilation: neither apartheid nor the melting pot" (de Benoist / Champetier2012, p. 34). Despite his break with racism de Benoist continues some perspectives of his early neo-fascist thinking. Just as the races in his early thinking also cultures should coexist in spatial separation. Thus, the critique of immigration is reaffirmed within the new culturalist framework (de Benoist / Champetier2012, p. 34 f.).

3 De Benoist / Champetier , p. 29. The term "pluriversum" originally introduced by William James was adopted by Max Scheler in his early philosophy of war (Scheler 1982) Like de Benoist Scheler described global modernity as a plurality of co-existing civilizations. In contrast to Hegel and later Husserl who justified the Europeanization of the whole world, the early Scheler negates cultural penetrations. The influences of European culture on China maintained only on the surface, as Scheler stresses with Ku Hung-Ming (Scheler 1982, p. 172 f; Hung-Ming 1911). As is well known Scheler corrected his early philosophy of separated civilizations in his late essay about "the age of adjustment" ("Das Weltalter des Ausgleichs"), developing the vision of reciprocal penetration between eastern and western cultures (Scheler 1976). 
The defense of the plurality of cultures is intimately linked with the newrighted project of a radical reform of democracy, which is guided by the model of the Greek Polis and the egalitarian order of German and Scandinavian tribes (de Benoist, 2011, p. 16 f.). The emergence of populist movements is often analyzed as a symptom of a representational crisis in democracies in the Western world. The New Right, however, not only tries to close the gap between established governmental parties and the people but questions the idea of parliamentary democracy itself. Alain de Benoist explicitly denies the usual preference of "modern" representative democracies suited to great populations over the model of direct democracy in antiquity. "In this respect, to argue that Greek democracy was only a direct democracy because it encompassed a small number of citizens is again rather simplistic. Direct democracy need not be associated with a limited number of citizens. It is rather primarily associated with a relatively homogeneous people conscious of what makes it such. The effective functioning of Greek democracy, as well as of Icelandic democracy, was first and foremost the result of cultural cohesion and a clear sense of shared belonging" (de Benoist 2011, p. 28).

Favoring traditions of direct participation, Alain de Benoist adopts a second element from ancient democracies. The Athenian democracy was based on ethnic homogeneity, which was ensured by the Periclean Citizenship Law of 451 B.C., as de Benoist explicitly indicates. "The most essential feature of citizenship was one's origin and heritage: Pericles was the 'son of Xanthippus from the deme of Cholargus'. From 451 B.C. one had to be born of an Athenian mother and father in order to become a citizen" (de Benoist 2011, p. 23). Far beyond historical reminiscences the ethnical basis of ancient democracy serves as a guideline for a deep reorientation of modern democratic states. "Democracy was rooted in a notion of autochthonous citizenship, which intimately linked its exercise to the origins of those who exercised it" (de Benoist 2011, p. 24). Attacking liberal democracy, the principles of freedom and equality aren't based on pre-state human rights but on ethnically anchored civil rights, as de Benoist frankly declares. "Liberty" means "first and foremost the liberty of the people, from which the liberty of citizens follows. In other words, it is the liberty of the people (or of the city) that lays the foundations for the equality of individual political rights, which is to say the rights enjoyed by individuals as citizens" (de Benoist 2011, p. 25).

Against this background liberalism as "the dominant ideology of modernity" becomes the "Main Enemy" of the New Right (de Benoist 2012, p. 14). Then, liberalism dissolves human beings from all forms of organic society. De Benoist's criticism of the liberal ideology does not refer only to the social atomism of the homo eoconomicus who seeks only his own advantage. Furthermore, de Benoist attacks also the idea of human rights as a dangerous ideology which undermines the priority of collective identities. The idea of pre-statal human dignity is criticized as an ideological product of Christianity and the Enlightenment. Thus, de Benoist denies modern liberalism, precisely a democratic state based on human rights, as a secularization of Christian individualism and abstract enlightened 
universalism. "Modern democracy organises atomised individuals into citizens, primarily viewing them through the lens of abstract egalitarianism. Ancient democracy was based on the idea of organic community; modern democracy, as an heir to Christianity and the philosophy of the Enlightenment, on the individual. The meaning of the words 'city', 'people', 'nation' and 'liberty' radically changes from one model to the other" (de Benoist 2011, p. 28). In this perspective de Benoist proposes the concept of an "organic democracy" as an alternative to liberal state. For the strength of a democracy depends on the "existence of a relatively homogeneous people". "The closer the members of a community are to one another, the more likely they are to have common sentiments, identical values, and the same way of viewing the world and social ties, and the easier it is for them to make collective decisions concerning the common good without the need for any form of mediation" (de Benoist 2011, p. 28). Strengthening the homogeneous national community, the idea of an "organic democracy" reaffirms the old idea of fraternity purified from Christian and transnational elements. "Fatherlands are the natural settings of fraternity whenever this is used to express one's duty towards those who share his heritage. The homeland is the natural framework of fraternity, whenever it expresses our duties to those who share a common heritage with us" (de Benoist 2011, p. 99).

Struggling for cultural hegemony of right-wing thinking, Alain de Benoist built up an international network of right-wing intellectuals. Thus, de Benoist held contact with Armin Mohler, the author of "Die konservative Revolution in Deutschland 1918-1932" (1949), who tried to separate conservativism from Nazism like the Nouvelle Droite in France. ${ }^{4}$ Since 1991 de Benoist also cooperates with Alexander Dugin, the main ideologue of neo-Eurasianism in Russia (Camus 2015), to mention just two expamples.

The relationships between de Benoist and right-wing populist parties are a complex field. Certainly, the New Right parties in Europe don't simply adopt de Benoist's idea of an organic democracy. Their ideological orientations result from power struggles between different groups within the parties. Furthermore each right-wing populist party articulates its own idea of "national homogeneity" reaffirming and modifying local illiberal ideologies of the $19^{\text {th }}$ and $20^{\text {th }}$ century. Nonetheless, de Benoist's concept of an "organic democracy" obviously serves as a theoretical matrix for New Right parties offering a certain framework for their diffuse ideological orientations.

4 Armin Mohler, a Swiss citizen, who entered into the Waffen-SS 1942, offers a comprehensive panorama of illiberal political traditions after the First World War. Mohler's work, originally a dissertation under Karl Jaspers and still published in new editions, became an important sourcebook for new rightest movements in the German speaking world. See Weiß 2017, pp. 39-63. The Nouvelle Droite was the model for the German New Right, especially of the "Thule-seminary" (Weber 1997, pp. 31-37). 
The direct and indirect influence of de Benoist on political parties can be observed in the Front National and the Austrian Freedom party. The FN was founded by neo-fascist movements (volunteers of NS organizations, collaborators of the regime of Maréchal Petain, supporters of the OAS in Algeria et al.). The spectacular rise of FN began with its ideological change which was mainly influenced by the think-tanks of the New Right. "This change in the ideological framework of the party went along with the decision taken in 1978 to put immigration at the core of its political platform, renouncing the neo-fascists' references in favor of a contemporary populist approach." (Roy 2016, p. 83). Although the new FN could not be understood without the ideology of the New Right, de Benoist still kept a certain distance to FN, even sharply criticizing its primitive theses and polemics (Taguieff1994, p. 225; Böhm 2008, pp. 122-125).

The ideas of de Benoist indirectly influenced also the ideological turn of the Austrian Freedom Party (FPÖ) initiated by Jörg Haider in 1986. After having marginalized liberal groups within the FPÖ, Jörg Haider proclaimed an ethnical reorientation in politics: "If politics is not built on ethnic principles, mankind has no future at all." (Haider 1994, pp.224) In the 1990's, Haider successfully perfected the strategies of the New Right-politics. Like the populist parties today, the FPÖ staged itself in the public sphere as the unique voice of the "people" which is exclusively defined by the FPÖ itself. Thus, Haider denounced political competitors as enemies of the state and even attacked democratic institutions, above all the constitutional court. Avant-garde artists such as Elfriede Jelinek, the later Nobel Prize Laureate for literature, socialist politicians and left-wing intellectuals were denounced as enemies of the Austrian "people" in public pamphlets. The slogan of the referendum of the FPÖ against foreigners in 1993 "Austria first" was adopted by a lot of populist parties meanwhile.

Jörg Haider even propagated the foundation of the Third Republic in Austria (Haider 1994, pp. 189-249), a project which can be compared with de Benoist's vision to transform the liberal state into an organic democracy. For this purpose Haider demanded to supplement the catalogue of the human rights with the ethnically defined "right to homeland" ("Recht auf Heimat") in the Austrian constitution (Haider 1994, pp. 86-106). The "right to homeland", however, is not a mere supplement to the catalogue of the human rights, because it reduces the universal dimensions of human rights into ethnic defined citizen rights as de Benoist propagates. Furthermore, the "right to homeland" understood as conservation of ethnic homogeneity paves the way for an authoritarian state. In a liberal and pluralistic democracy, "national identity" is the subject of public debates based on certain human rights, especially the freedom of expression and assembly. Since different groups have different views on "national identity", the "right to homeland" secured by public authority unavoidably represses social pluralism. For this account, instead of adapting themselves to the fluctuating moods of the people, new rightest movements already know "the" will of "the" people, and, above all, who really belongs to the people. 
The Ideology of the New Right and Religious Conservativism

At this point we can observe the dialectical role of the New Right in the politics of representation. On the one hand, the New Right emerges as a reaction against the representational crisis in modern societies during the last decades. On the other hand, promoting a new politics of representation, the New Right produces a deep crisis of political representation. Claiming to represent the "people", the socalled populist parties paradoxically excludes all groups which don't belong to the holistic corpus of the "people" ("Volk"). This is the central thesis of Jan-Werner Müller's approach to populism which can be applied both to right-wing and left wing parties: "populists claim that they, and only they, represent the people [...] The populist core claim also implies that whoever does not really support populist parties might not be part of the proper people to begin with." (Müller 2016, p. 20) In regard to right-wing populism I would like to specify Müller's thesis. In the long run, right-wing populist parties aim at an organic democracy outlined by de Benoist.

In order to re-construct modern liberal states into an organic democracy, the New Right meanwhile developed a set of political strategies which are inspired by de Benoist: strengthening direct democracy through referendums; weakening the separation of power and the judicial institutions, specifically the Constitutional Court; fostering cultural and ethnical homogeneity by state control over the media and cultural life; and not at least a restriction of immigration policy.

Thus, the ideology of the New Right tends to a new authoritarianism but not to a simple renewal of old fascism. Identifying the right-wing populist parties with Neo-fascism in public debates is a counterproductive strategy which mistakes their real ideological agenda and allows them to renounce critique as left-wing propaganda. Nonetheless, elements of the old fascism are not totally eliminated in the heterogeneous populist parties which consist of quite different groups, including neo-fascist milieus. As is well-known, Jean Marie Le Pen often expressed antisemitism and posed in question the historicity of the holocaust. And Jörg Haider defended members of the Waffen-SS and the employment policy of the Nazis. Neo-fascist expressions of some members of populist parties, however, must be differentiated from the ideological orientations recorded in party programs.

\section{Viktor Orbán's Contradictory Synthesis between New Right Ideology and Christianity}

Jörg Haider could only articulate a diffuse vision of a Third Austrian Republic based on ethnic principles. The dreams of the new state inspired by the ideology of the New Right were paradoxically realized by a Christian democratic politician and member of the European People's Party group (EPP Group), namely Victor Orbán. The rise of Fidesz, which was originally a liberal party, reveals the dialectical links between extreme economic liberalism and the New Right. During 
the liberal era after 1989 important industries and the financial sector came under the control of foreign investors. In 2008 the Hungarian people severely suffered under the financial crisis. The GNP fell by 20 percent in one year; families lost thousands of US-dollars within a few months. Hungarian companies control only $10 \%$ of the industrial and financial economy of the country. The overwhelming victory of Orbán 2010 obviously was an eruptive reaction against the economic liberalism during the last decades.

Victor Orbán, however, did not just take a more protectionist course in economic politics, but used the two-thirds majority for a radical reconstruction both of Hungarian state and civil society. The state media were brought under the control of the government. The constitutional court was disempowered. The main project of the new government, however, was a new constitution, which had been enforced without agreements with oppositional parties, a coup, which was legally possible, but stands in contrast to the democratic ethos. Only a party which understands itself as the authentic voice of the "people" is able to adopt a new constitution beyond a broad consensus of all political groups. In 2002, Orbán already expressed his new-rightest thought in a well-known statement after his electoral defeat: "The Mother Country (Haza) cannot be in opposition!" (cited according to Péteri).

The preamble of the new constitution describes Hungary no longer as a republic, but as a Christian nation founded by the Holy Stephen. After the national narrative which doesn't mention the historical role of other groups as the Jews or the Roma, the constitution integrates a catalogue of human rights. Unlike other Western constitutions, which start with idealizing representations of the national history, too, the new Hungarian constitution explicitly oblige the constitutional court to justify its decisions in the light of the nationalistic preamble (Müller, 2012, pp. $28 \mathrm{f}$; ; Halmai 2014). Thus the ethnic community defined only by one party became the normative basis of the whole state order prior to the human rights. For this reason, the new Hungary promulgated the first constitution which was built on the core principle of the ideology of the New Right. Orbán himself underlined the ethnic roots of the Hungarian state on a speech in the Ópusztaszer in 2012. "From the moment of our births, our seven tribes enter into an alliance, our StKing Stephen establishes a state, our armies suffer a defeat at the battle of Mohács, and the Turul bird is the symbol of national identity of the living, the deceased and the yet-to-be-born Hungarians." ${ }^{5}$ Moreover, Orbán publicly affirmed the priority of the ethnic community over human rights, a core element of the organic democracy of de Benoist. As Orbán frankly stated in the Swiss journal "Weltwoche" (No 46/2015), the European elites are only debating about "shallow and secondary topics. Nice things as human rights, progress, peace, openness, tolerance. We do not talk about freedom, we do not talk about Christianity, we do

5 Viktor Orbán 2012; the English translation is adopted from Ádam / Bozóki 2017, p. 136. 
not talk about the nation, and we do not talk about pride. Brutally said: What dominates the European public today is only European liberal blabla over nice, but secondary topics."

At this point the question arises, how it is possible that a Christian politician questions the universality of the human rights in the name of ethnic identity which de Benoist justified with a new anti-Christian paganism. We can find an answer for the question in the speech of Orbán in Kötcse on the $5^{\text {th }}$ of September 2015, in which Orbán explained the opposition between liberal identity and identity as the most important ideological frontline in present times; "if we fight well in this debate, to restore the prestige and appeal of national identity and Christian identity, in opposition to the liberal identity (Orban 2015)". Orbáns speech is explicitly a commentary to the new constitution, because "the Hungarian constitution - adopted at a time when an immigration crisis was still nowhere to be seen - is superbly suited to strengthening this Christian and national identity in the eyes of all and in opposition to the ruling liberal identities in Europe today" (ibid.).

Orbán identifies liberalism with an egalitarian moral cosmopolitanism fostered by legal regimes of human rights. In accordance to de Benoist, human rights are qualified as a set of particular values of Western culture, which has been violently imposed upon foreign peoples. The refugee crisis is one of the consequences of the missionary imperialism of Europe. "After having proclaimed global, universal human rights, having forced our ideology on them and having elevated freedom of information above all else, having sent our celebrities into their homes, now we are surprised that they are knocking on our door" (ibid).

Transforming the world into a global village, liberal cosmopolitanism endangers prosperity and self-assertion of Europe. For this reason liberal identity must be replaced by a by Christian identity as Orbán programmatically proclaims. The core of Christian identity is defined by an ethics which differentiates moral responsibilities according to concentric spheres of social live:

"[W]e know that the liberal feels responsible for the whole world because they are a good person, everything happening in the world causes them pain, and their soul feels heavy with the burden. In opposition to this approach, how does our identity stand up? I think that the Christian identity [...] reveals to us a completely clear order of importance or priority. First of all, we are responsible for our children, then for our parents. This comes before all else. Then come those with whom we live in our village or town. Then comes our country, and then everyone else may come.” (Orbán 2015)

Orbán criticizes Christian circles to be eager to the liberal ideology, too. Against Christian demands for humanitarian refugee politics, Orbán attacked even Church officials who are transforming Christian charity into a political principle. The Christian commandment of love refers only to the private space as Orbán stresses. 
Victor Orbán's defense of the "Christian identity" obviously mixes pagan and Christian elements into a highly ambiguous synthesis. However, a critique of the contradictions between the combination of New Right ideology and Christian ethics need further clarifications.

Firstly: From a historical viewpoint, the "liberal identity" attacked by Orbán as abstract cosmopolitanism was originally a Christian idea. Admittedly, the ethics of global responsibility cannot be traced back to the Bible, but it was developed by Christian philosophies in the $16^{\text {th }}$ century. According to the famous parable of the Good Samaritan in Luke 10:25-37, Christians are obliged to help people in need regardless of their religious or ethnic affiliation. However, the Samaritan doesn't feel immediately responsible for the whole humankind. For instance, the victims of Roman imperialism were not subject to Christian responsibility in the early era of the church. The idea of concrete global responsibility was developed by the "School of Salamanca" during the European expansion since the $15^{\text {th }}$ century (Schelkshorn 2009, pp. 205-298; Schelkshorn 2012). Shocked by the imperial violence of the Spaniards in Peru, Francisco de Vitoria laid the foundation for the modern theory of international law, which contains not only the right to travel and to trade, but also the right to migration and even to become a citizen in a foreign country. In addition, reacting to the reports on human sacrifices of the Aztecs, Vitoria postulated to defend innocent men from unjust death even if they live far away from our own life world as a universal moral obligation. Extending moral responsibility to the whole mankind, Vitoria paved the way for an ethics of global solidarity including humanitarian intervention which still is a subject of controversies until now.

That means: The moral cosmopolitan condemned by Orbán as liberal ideology originally was a utopian vision of Christian philosophy of the $16^{\text {th }}$ century based on the Stoic and biblical idea of the unity of humankind. No doubt, Vitoria's cosmopolitanism was already criticized by Christian theologians, for instance by Luis de Molina in den $16^{\text {th }}$ century. Hobbes completely rejected international law, which was theoretically founded again mainly by Kant (Cavallar 2011, pp. 39 108). Nonetheless, the current international conventions on asylum and aliens however, restrict Vitoria's Christian vision of a new world society (Cavallar 2002).

Secondly, the doctrine of concentric spheres of moral duties opposed to "liberal cosmopolitanism" by Orbán originally can be found both with Cicero and the Mencius. The idea of a gradation of moral duties was a critical response to the problem of excessive demands of universalistic morality and to an extreme egalitarianism. For instance, the Chinese philosopher Mo Ti, who developed one of the first universalistic ethics in China, propagated that we have the same obligations to all men whether they were family members or foreigners. The ethics of Mo Ti was sharply criticized by Mencius who focused on the priority of familiar duties. Moral education has to start with the relationship between the members of the family. However, the doctrine of different spheres does not contradict ethical universalism. Both Cicero and Mencius advocate a step-wise expansion of moral 
responsibility, which primarily is applied by the family and ultimately should encompass the whole of mankind. ${ }^{6}$ In this sense the theory of concentric circles was adopted by Christian ethics, too.

Thirdly, the relationship between Christian morality and politics addressed by Orbán is an extremely complex problem that can't be systematically treated in this context. I would like to outline only one aspect: Certainly, the biblical commandment of love firstly is directed to Christians in their everyday and private life. In a strict sense Christian love (agape) isn't a moral norm but a gift or an effect of the divine grace. Thus it is impossible to deduce concrete political norms immediately from the Christian agape. For instance, biblical commands to respect foreigners surely foster moral sensibility for refugees; but they don't dispense us from searching for strategies to deal with the extremely complex refugee crisis in these present days. Certainly, an ethics of global responsibility has to take into account the limited capacities of states that accept asylum seekers. Overall, we have to concede that nobody has all of the convincing answers to this great problem in the early 21 th century.

The problem with new right policies concerning migration and asylum doesn't consist in articulating certain and neglected problems but in the ethnically reduced view of the refugee crisis as a whole. New right parties don't discuss difficult questions concerning the quantity of refugees and the limitation of the social institutions. The main aim of migration politics is to avoid any migration in order to protect the ethnic composition of the nation. Under the spell of an ethnic ideology even the moderate quote of about 1400 refugees was refused by Orban as an intolerable pressure from abroad.

The question of asylum is the pitfall for any universal ethics. The exclusive focus on ethnic identity contradicts the universal claims of Christian ethics. Therefore Christians engaged in the refugee crisis must not agree in the strategies, but they will recognize central values of its own morality in the secular human rights conventions, including the conventions on asylum and aliens. By the way, those who transformed the Hungarian republic into a Christian state should not accuse Christian human rights groups of ignoring the difference between private and political ethics.

6 See Mencius 1970, p. 143 f; A7: "Treat with the reverence due to age the elders in your own family, so that the elders in the families of others shall be similarly treated; treat with the kindness due to youth the young in your own family, so that the young in the families of others shall be similarly treated - do this, and the kingdom may be made to go round in your palm [...] The language shows how king Wen simply took his kindly heart, and exercised it towards those parties. Therefore the carrying out his kindness of heart by a prince will suffice for the love and protection of all within the four seas, and if he do not carry it out, he will not be able to protect his wife and children." Cf. also Opitz 2000, pp. 113-156 (Mencius); pp. 159-190 (Mo Ti). 
Fourthly: Alain de Benoist affirms and reverses Hegel's thesis that the French Revolution is based on the ethical universalism of Christianity. In the middle of the $20^{\text {th }}$ century Christian thinkers as Jacques Maritain laid important foundations for a plural democracy and even the UN Declaration of Human Rights on the basis of the Christian doctrine of natural law. According to Maritain, the dignity of the human person transcends historical communities based on ethnic descent. If the ethnic community obtains a principal priority over the person, there is no bulwark against political totalitarianism. The respect for the human person, however, does not negate the relative importance of national or ethnic forms of the community. Like de Benoist, Maritain criticizes social atomism and laissez faire economy as liberal ideologies (Maritain 1996, ch. I,3; IV,4). In contrast to de Benoist, however, Maritain affirms the universal horizon of the modern ideal of fraternity: Under the inspiration of the Gospel in history the "secular conscience has understood that in the temporal social and political order itself, not only is there civic friendship, as the ancient philosophers knew it [...] but this very friendship between citizens cannot prevail in actual fact within the social group unless a stronger and more universal love, brotherly love, is installed in it, and civic friendship, itself becoming brotherhood, overflows the bounds of the social group to extend to the entire human race" (Maritain 1945, p. 36).

To sum up: The synthesis between Christianity and the ideology of the New Right unavoidably negates core intuitions and innovative theological traditions of Christian ethics. The self-appointed defenders of the Christian Occident paradoxically question the historical achievements of European culture, namely the democratic constitutional state and the human rights which were inspired by Christian Ethics as philosophers from Hegel to de Benoist himself acknowledged. Unable to recognize their own Christian thoughts in the emancipatory ideals of modernity Christian alliances with the New Right appeal to old models of Christian authoritarian state continuing antimodernist traditions of the $19^{\text {th }}$ and early $20^{\text {th }}$ century.

At this point I would like to add a reflection concerning the critique of de Benoist of the doctrine of human rights as imperialist ideology of the West. Without denying the abuse of human rights for geopolitical interests it must be remembered that the UN declaration of the human rights already emerged from some cross-cultural dialogues. The erosion of a mere Eurocentric foundation of the human rights can already be observed in the philosophy of Maritain. In the 1940s Maritain still insisted that human rights cannot be founded outside Christian morality (Martian 1944). As chair of the French delegation of the UNcounsel, however, Maritain was confronted with different foundations of human rights, especially by the Chinese and Indian thought. The UNESCO symposium documented a broad spectrum of views of human rights, containing "in itself an important object lesson" (Maritain 1950, p. 12). Not by chance, the Chinese member of the counsel, referred to Mencius (Chung-Shu Lo 1950, p. 187). The cross-cultural experience provoked a certain shift of Maritain's social philosophy 
differentiating between theoretical and practical levels in the search for a consensus about human rights. ${ }^{7}$ Although the "ideological contrast is irreducible and no theoretical reconciliation is possible" (Maritain 1950, p. 13) ${ }^{8}$, the idea of the human rights could find general acceptance in concrete political praxis. "In the field of practical conclusions [...] agreement on the joint declaration is possible, given an approach pragmatic rather than theoretical" (Maritain 1950, p. 11). ${ }^{9}$ Anticipating Rawls theory of an "overlapping consensus" Maritain makes first steps towards a cross-cultural foundation of human rights. After more than half a century, philosophies of Africa, the Islamic World, Latin America and East Asia question the limits of former Eurocentric and even colonialist distortions of former philosophical frameworks. Thus, de Benoist's ethnopluralist vision of world society could be overcome through a global and continuous cross-cultural dialogue on human rights.

\section{Final Remarks: Some Challenges for an Ethical Critique of the New Right}

The New Right outlined by Alain de Benoist refuses the universality of the human rights as an ideology of Christianity and Enlightenment. Therefore, Christian alliances with new-rightest movements involve themselves in ideological contradictions. The ideology of the New Right, however, is highly ambiguous. On the one hand, de Benoist breaks with old fascism; on the other hand, he restores the priority of an ethnic concept of the "people" ("Volk"). While appealing to the great ideals of the French Revolution their universalistic claims are eroded by the ethnic concept of fraternity which restricts the pluralism in modern societies in a dangerous way. Since New Right parties engage themselves in the democratic competition playing even the language game of democracy and "human rights",

7 Maritain 1950, p. 10 f.: "I am quite certain that my way of justifying belief in the rights of man and the ideal of liberty, equality and fraternity is the only way with a firm foundation of truth. This does not prevent me from being in agreement on these practical convictions with people who are certain that their way of justifying them, entirely different form mine or opposed of mine, in its theoretical dynamism, is equally the only was founded upon truth."

8 According to Maritain the different foundations of the human rights can be divided into two main schools, on the one hand theories of "Natural Law", on the other hand theories, which interpret human rights as "relative to the historical development of society, and are themselves constantly variable and in a state of flux" (Maritain 1950, p. 13).

9 Cf. Maritain 1950, p. 10: "it is necessary to make the appropriate distinction between the rational justifications involved in the spiritual dynamism of a philosophic doctrine or religious faith, and the practical conclusions which, although justified in different ways by different persons, are principles of action with a common ground of similarity for everyone." 
the authoritarian agenda of their political aims often remains hidden for great parts of the people. Thus, the regime of Orbán and the Polish PiS reveal the authoritarian politics of the New Right.

Ethical criticism of the New Right, however, is not only confronted with its hidden agenda but traced in the complex history of human rights itself. Finally I would like to briefly hint at some of the problems.

In the French Declaration in 1789, human and citizen rights build an ambiguous unity. For that reason, the universal claims of the human rights were reduced in a certain way during the $19^{\text {th }}$ and early $20^{\text {th }}$ century. After the dissolution of the Habsburg monarchy huge masses of stateless persons revealed the painful reduction of the human rights to citizen rights in the constitutional regimes of European states. Shocked by the NS-barbarianism the assembly United Nations reaffirmed emphatically the universal claims of the human rights. The UN Declaration as such is a moral declaration which had to be implemented by legal frameworks, both national and international, in the Post-war era. For that reason liberal constitutions of the Western world contain a complex mixture of citizen rights and transnational human rights. Liberal theories of democracy don't totally dissolve the "nation" by atomistic individualism. The debate between liberals and communitarians in political philosophy judged different constellations between nation, state and human rights. Even Jürgen Habermas doesn't eliminate the concept of "nation" in his philosophy of right (Habermas 1997, 128-191). At this point we can specify the ideological thrust of new-righted movements and parties: The New Right dissolves the tense balance between human rights, state and nation in favor to an ethnic concept of nation. In addition, the liberal idea of human rights knows not only individual, but also collective rights, which are restricted to minority groups. Thus, the New Right transposes minority rights on the legal order of the society as a whole.

The confrontation with the New Right, however, cannot be restricted to political philosophy in a strict sense of the term. As de Benoist denies the universality of human rights, a radical critique of the New Right is faced with the search for a rational justification of universal ethics. The current philosophical debates in political philosophy and social sciences are dominated by postmodern, poststructuralist, non-foundationalist discourses which de-construct problematic universalistic paradigms without constructive foundations of universal ethics. For this reason, philosophers of the New Right use not only Gramsci for their own ideology but also Foucault and elements of differentialist culturalism. Of course, poststructuralist and non-foundationalist philosophies offer sharp instruments to criticize the holistic view of an organic democracy. Nonetheless, constructive justifications of universal ethics still remain a neglected and sometimes even an eliminated field in contemporary philosophies.

Michel Foucault distinguished between two families of founders, on the one hand philosophies which lay the foundation stone and build up, on the other hand philosophies which dig and open a space for new forms of thinking (cf. Foucault 
1994, p. 534). Foucault dedicated his work to the second type of discourses. Insofar modern philosophy is reflecting on its own time since Kant philosophical discourses are faced with the task of a critical diagnosis of the social and cultural world. Lacking an ahistorical point of view the question "What we are now?" has to be treated from our own experiences and involvements in historical processes and struggles. Thus, modern philosophies emerge from a certain decision as Foucault emphasizes: "I think that the ethico-political choice we have to make every day is to determine which is the main danger" (Foucault 1983, p. 232). I suppose that the rise of the New Right requires philosophies which are engaged in the cross-cultural foundations for a global ethics and human right regime.

\section{References}

Ádam, Zoltán / Bozóki, András: “The god of Hungarians'. Religion and Right-wing Populism in Hungary", in: Nadia Marzouki, Duncan McDonell, Olivier Roy (Eds.): Saving the People. How Populists Hijack Religion. London, Hurst \& Company 2016, pp. 219-147.

De Benoist, Alain / Champetier, Charles: Manifesto for a European Renaissance. London, Arktos 2012.

De Benoist, Alain: “Contre tous les racismen”, in: Élements 33 (1974-1975), pp. 13-40.

De Benoist, Alain: The Problem of Democracy. London, Arktos 2011.

Böhm, Michel: Alain de Benoist und die Nouvelle Droite. Ein Beitrag zur Ideengeschichte im 20. Jahrhundert. Mit einem Vorwort von Frank-Lothar Kroll, Münster, LIT 2008.

Camus, Jean Yves: "A Long-Lasting Friendship. Alexandre Dugin and the French New Right", in: Marlene Laruelle (Ed.): Eurasianism and the European Far Right: Reshaping the Europe-Russia Relationship, London, Lexington 2015, pp. 79-96.

Canovan, Margeret: Populism, New York, Harcourt Brace Jovanovich 1981.

Cavallar, Georg: The Right of Strangers: Theories of International Hospitality, the Global Community, and Political Justice since Vitoria, Aldershot, Ashgate 2002.

Cavallar, Georg: Imperfect Cosmopolis. Studies in the History of International Legal Theory and Cosmopolitan Ideas, Cardiff, University of Wales Press 2011.

Foucault, Michel: "On the Genealogy of Ethics: An Overview of Work in Progress", in: H Dreyfus / Paul Rabinow: Michel Foucault. Beyond Structuralism and Hermeneutics, Chicago, University of Chicago Press 1983, pp. 229-252.

Foucault, Michel: "C'était un nageur entre deux mots (entretiens avec C. Bonnefoy)", in: Michel Foucault. Dits et Écrits 1954-1969. Tom. 1, édition établie sur la direction de Daniel Defert et François Ewald avec la collaboration con Jacques Lagrange, Paris, Gallimard 1994, pp. 534-537.

Fukuyama, Francis: “The End of History?”, in: The National Interest 16 (1989), pp. 3-18. Habermas, Jürgen: Die Einbeziehung des Anderen. Studien zur politischen Theorie, Frankfurt am Main, Suhrkamp ${ }^{2} 1997$.

Halmai, Gábor: "An Illiberal Constitutional System in the Middle of Europe”, in: European Yearbook of Human Rights (2014), pp. 497-514. 
Heinisch, Reinhard C. / Holtz-Bacha, Christina / Mazzoleni, Oscar (eds.): Political Populism. A Handbook, Baden-Baden, Nomos 2017.

Hung-Ming, Ku: Chinas Verteidigung gegen europäische Ideen, Jena, Paquet 1911.

Laruelle, Marlene (Ed.): Eurasianism and the European Far Right: Reshaping the Europe-Russia Relationship, London, Lexington 2015.

Lo, Chung-Shu: "Human Rights in the Chinese Tradition", in: Human rights. Comments and interpretation. A Symposium edited by UNESCO, London, New York, Wingate 1950, pp. 186-190.

Maritain, Jacques: Integral Humanism, Freedom in the Modern World, and a Letter on Independence, ed. by Otto Bird. Notre Dame, Ind., Univ. of Notre Dame Press 1996. Maritain, Jacques: The Rights of Man and Natural Law, London, Bles 1944.

Maritain, Jacques: "Introduction", in: Human rights. Comments and interpretation. A Symposium edited by UNESCO, London / New York, Wingate 1950, pp. 9-17.

Marzouki, Nadia / McDonell, Duncan / Roy, Olivier (eds.): Saving the People. How Populists Hijack Religion, London, Hurst \& Company 2016.

Mencius: The works of Mencius. Translated by James Legge, New York, Dover Publications 1970.

Mohler, Arnim: Die konservative Revolution in Deutschland 1918-1932. Ein Handbuch, zweite, völlig neue bearbeitete und erweiterte Fassung, Darmstadt, Wissenschaftliche Buchgesellschaft Darmstadt 1972.

Mudde, Cas: Populist Radical Right Parties in Europe, New York, Cambridge University Press 2007.

Müller, Jan-Werner: Wo Europa endet. Ungarn, Brüssel und das Schicksal der liberalen Demokratie, Berlin, Suhrkamp 2012.

Müller, Jan-Werner: What is Populism, Philadelphia, University of Pennsylvania Press 2016.

Opitz, Peter: Der Weg des Himmels. Zum Geist und zur Gestalt des politischen Denkens im alten China, München, Fink 2000.

Priester, Karin: Rechter und linker Populismus. Annäherung an ein Chamäleon, Frankfurt am Main, Campus 2012.

Roy, Olivier: "The French National Front. From Christian identity to Laicité", in: Nadia Marzouki, Duncan McDonell, Olivier Roy (eds.): Saving the People. How Populists Hijack Religion, London, Hurst \& Company 2016, pp. 79-93.

Scheler, Max: "Der Mensch im Weltalter des Ausgleichs", in: Gesammelte Werke IX: Späte Schriften, ed. by Manfred S. Frings, Bern, München 1976, pp. 145-170.

Scheler, Max: "Der Genius des Krieges und der Deutsche Krieg", in: Gesammelte Werke IV. Ed. by Manfred S. Frings, Bern / München 1982, pp. 14-105.

Schelkshorn, Hans: Entgrenzungen. Ein europäischer Beitrag zum philosophischen Diskurs über die Moderne, Weilerswist, Velbrück Wissenschaft 2009.

Schelkshorn, Hans: "The Change of Geographical Worldviews and the Constitution of a Modern Cosmopolitanism by Francisco de Vitoria", in: Sigrid Müller, Cornelia Schweiger (ed.): Between Creativity and Normmaking. Tensions in the Early Modern Era, Leiden, Brill 2012, pp. 165-188.

Schelkshorn, Hans: "Wider die Instrumentalisierung des Christentums. Zur Unvereinbarkeit von neorechter Ideologie und christlicher Moral", in: Walter Lesch 
(ed.): Christentum und Populismus. Klare Fronten?, Freiburg / Basel / Wien, Herder 2017, pp. 26-37.

Taggart, Paul: Populism, Philadelphia, Buckingham 2000.

Weber, Iris: Nation, Staat und Elite. Die Ideologie der Neuen Rechten, Köln, PapyRossa 1997.

Weiß, Volker: Die autoritäre Revolte. Die Neue Rechte und der Untergang des Abendlandes, Stuttgart, Klett-Cotta 2017.

Zea, Leopoldo: Fin del siglo XX ¿Centuria perdida?, México, FCE 1996.

\section{Internet Sources}

Orbán, Victor: Speech in Kotcse 2015, available here: http://www.kormany.hu/en/theprime-minister/the-prime-minister-s-speeches/viktor-orban-s-speech-at-the-14thkotcse-civil-picnic [September 25 ${ }^{\text {th }}, 2018$ ].

Péteri, György: "Should We Really Be Surprised by Where Viktor Orbán's Hungary is Heading?”, in: Transit-online, http://www.iwm.at/transit/transit-online/really-surpri sed-viktor-orbans-hungary-heading/ [September $\left.25^{\text {th }}, 2018\right]$.

Hans Schelkshorn, Department for Christian Philosophy, University of Vienna, Schenkenstraße 8,1010 Vienna, Austria, e-mail: johann.schelkshorn@univie.ac.at

Citation: Schelkshorn, Hans: "The Ideology of the New Right and Religious Conservativism Towards an Ethical Critique of the New Politics of Authoritarianism", in: Appel, Kurt / Raschke, Carl (eds.): The Crisis of Representation (J-RaT 2018 / 2) pp. 124141.

Datum der Publikation: 21.01.2019 